DOI: $10.5277 /$ epe 160408

\title{
APPLICATION OF MULTI-CRITERIAL ANALYSIS TO EVALUATE THE METHOD OF UTILIZATION OF SLUDGE FROM SMALL WASTEWATER TREATMENT PLANTS WITH SUSTAINABLE DEVELOPMENT OF RURAL AREAS
}

\begin{abstract}
A multi-criterial analysis has been proposed for choosing the optimal method of dewatering and final disposal of sludge from small wastewater treatment plants. A multi-criterial analysis is a method of compromise programming, selecting the best solution from four possible technological variants of sludge treatment. Based on these calculations, the best method from 4 variants was selected. It can be used in selection of optimal solution of sludge treatment and designing of small communities in rural areas.
\end{abstract}

\section{INTRODUCTION}

The side effect of each wastewater treatment process is generation of sludge, which could amount to as much as several percent of volume of treated wastewater. Moreover, due to sanitation threat it might cause serious problems. One such rising problem is rapid overconsumption of natural resources including crucial resources to agriculture such as phosphorous. Therefore, more and more attention is brought to the necessity of waste recycling. One of the pressing issues is utilization of sludge from small

${ }^{1}$ Institute of Water Supply and Environment Protection, Department of Environment Engineering, Cracow University of Technology, ul. Warszawska 24, 31-155 Cracow, Poland, corresponding author Z. Mucha, e-mail: zmucha@ vistula.wis.pk.edu.pl

${ }^{2}$ Krosno State College, Polytechnic Institute, Rynek 1, Krosno, Poland.

${ }^{3}$ Department of Environmental Engineering and Geodesy, Faculty of Production Engineering, University of Life Sciences in Lublin, ul. Leszczyńskiego 7, 20-069 Lublin, Poland.

${ }^{4}$ Institute of Soil Science, Environment Engineering and Management, Faculty of Agrobioengineering, University of Life Sciences in Lublin, ul. Leszczyńskiego 7, 20-069 Lublin, Poland. 
wastewater treatment plants in rural areas, which leads to the challenging issue of development of tools for evaluation and comparison of the methods of sludge utilization in agriculture [1-3]. The most common reclamation processes are the following: land application, composting, liming, drying, and incineration. Another method of sludge reclamation is organic recycling, based on biological transformation into humus on soilplant beds planted with reeds. The decision-making process for the technological solution requires taking numerous criteria into account, aside from the technology itself, e.g. ease of operation, reliability, economical aspects, impact on the environment, and aesthetics of the facility.

The article presents a method of utilizing multi-criteria analysis as a supplementary tool to the selection of the appropriate technological solution of sludge treatment in smallscale treatment plants, with taking into account both, technological, as well as ecological and economical criteria according to sustainable development principles [4-6].

\section{MULTI-CRITERIAL ANALYSIS FOR SELECTION OF PROPOSED TECHNOLOGICAL SOLUTIONS}

Multi-criterial analysis is a mathematical tool used for solving decision-making problems [7-9]. To define such problems, one must define the variants that will be analyzed as well as criteria of evaluation. The criteria form a measure of how well the tasks would be achieved in each variant and should be expressed in a number. In this decision-making study the evaluated solutions are the methods of treatment and disposal utilization of sludge from small wastewater treatment plants $[8,10,11]$. Evaluation criteria were chosen in accordance with the principles of sustainable development.

\section{SELECTION OF EVALUATED TECHNOLOGICAL VARIANTS OF SLUDGE TREATMENT}

For the comparative multi-criterial analysis, a wastewater treatment plant with the capacity of $350 \mathrm{~m}^{3} \cdot \mathrm{d}^{-1}$ and the equivalent inhabitant number (EIN) equal to 2500 was chosen. This is an mechanical-biological plant, with a sequencing batch reactor (SBR) and separate aerobic sludge stabilization. A mechanical part takes place in a screen-sand remover.

For dewatering and disposal of stabilized sludge the following methods were proposed:

- drying-bed under a shade, and sludge transportation to a composting facility (drybed),

- filter bags and sludge transportation to a composting facility (bagfil),

- vegetation-bed planted with grass and humus production (Bio-vt ${ }^{\mathbb{R}}$ technology),

- filtration press and disinfection with lime (pressfil). 
It was assumed that after dewatering and stabilization, the sludge would be used for soil enrichment in each variant. Proposed variants are shown in Fig. 1.

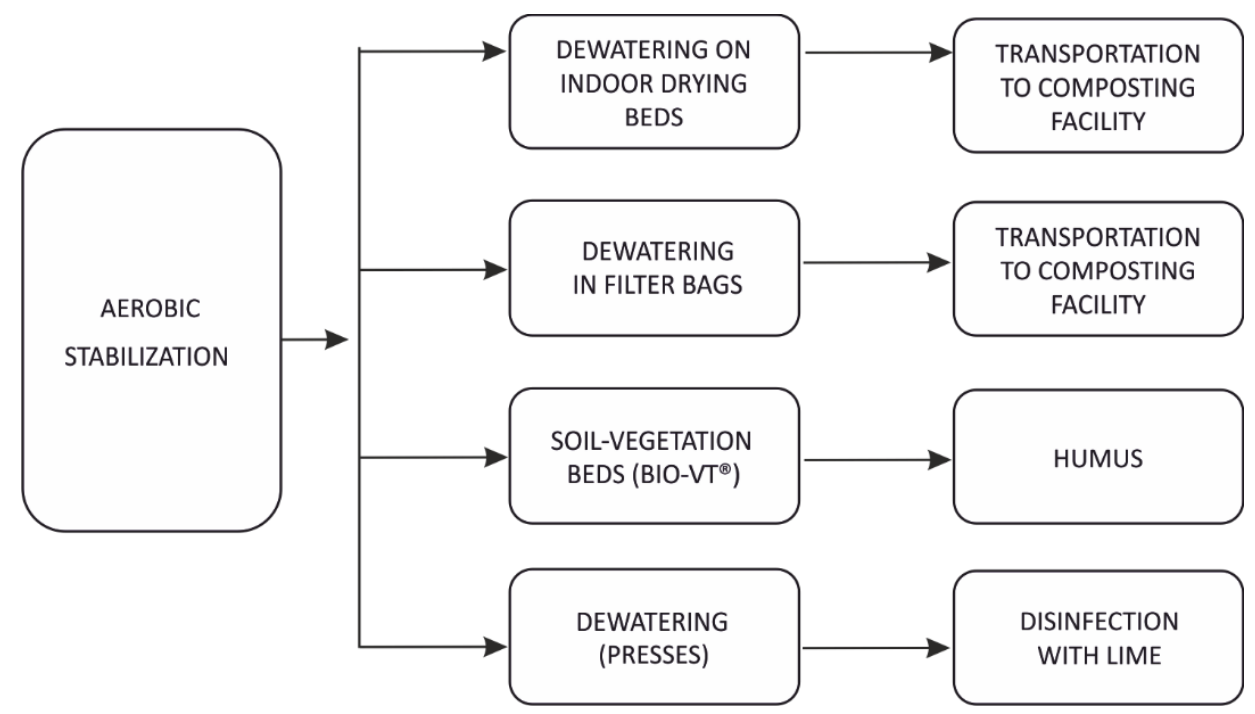

Fig 1. Proposed variants of dewatering and utilization of sludge

\section{SELECTION CRITERIA AND ASSUMPTIONS}

To define the criteria, an individual approach has to be taken to each decision problem. Various criteria are selected according to size of an object, used technological and technical solutions, and a goal to which an analysis is done. For selection of optimal engineering solutions, usually, environmental, economical, technical, and social aspects are considered. Most important are environmental criteria, including whose which are related to use of natural resources, emission of various pollutants to environment, pollution protection and control.

In evaluation of sludge treatment and disposal from small wastewater treatment, the following should be considered [8-10]:

- environmental criteria,

- technical criteria with particular emphasis of simplicity of operation,

- economical criteria.

Environmental criteria are related mainly to impact on natural environment in a region at a stage of operation as well as closure of facility and final utilization and disposal of sludge. Since sludge is considered a waste, its final utilization is directly related to obeying local laws and regulations, including the Waste Act. 
Technical criteria should consider only such solutions which guarantee complete sludge utilization with respect of sustainable development. Moreover, location of small plants close to the houses requires consideration of aesthetic aspects as well as odors. Following aspects could be included in this group:

- required land area for each analyzed technology,

- aesthetics of solution, including how well it fits to the landscape

- simplicity of operation, including frequency and time of maintenance,

Economical criteria are very important as well. Their advantage is that they are easy to value and measure. In this analysis, the costs of construction and operation were considered. It is possible to combine both these costs into one average annual cost, but in the case of multi-criteria analysis it is better to separate them by putting different weight to each of them. All criteria assumed in this analysis are shown in Table 1.

Social criteria are difficult to describe and very often are changing during the investment process. Therefore, in this research they are described qualitatively and estimated with an expert method. Their values allow describing acceptance and goodwill of local society for particular technological solutions, and could change depending to whom a solution concerns. Difficulties in their estimation are also related to their connections with economical and environmental criteria [3, 12-15].

Table 1

Comparison of sludge dewatering and disposal methods from small wastewater treatment plants

\begin{tabular}{|c|c|c|c|c|c|}
\hline No. & Criterion & Drybed & Bagfil & Bio-vt ${ }^{\mathbb{B}}$ & Pressfil \\
\hline 1 & $\begin{array}{l}\text { Investment } \\
\text { costs }\end{array}$ & $\begin{array}{l}\text { construction } \\
161760 \$\end{array}$ & $\begin{array}{l}\text { construction } \\
\text { with equipment } \\
88230 \$\end{array}$ & $\begin{array}{l}\text { construction } \\
\text { license } \\
\text { and service } \\
\text { in the first year } \\
138230 \$\end{array}$ & $\begin{array}{l}\text { construction } \\
\text { with equipment } \\
138230 \$\end{array}$ \\
\hline 2 & $\begin{array}{l}\text { Operation } \\
\text { costs }\end{array}$ & $\begin{array}{l}\text { operation } \\
\text { with transportation } \\
\text { for composting } \\
4700 \$ / y r\end{array}$ & $\begin{array}{l}\text { operation } \\
\text { with transportation } \\
\text { for composting } \\
8,820 \$ / \mathrm{yr}\end{array}$ & $\begin{array}{l}\text { operation } \\
\text { with grass seeds } \\
2,350 \$ / y r\end{array}$ & $\begin{array}{l}\text { operation costs } \\
5,880 \$ / \mathrm{yr}\end{array}$ \\
\hline 3 & $\begin{array}{l}\text { Land requirements } \\
\mathrm{m}^{2} / \mathrm{EIN}\end{array}$ & $0.23 \mathrm{~m}^{2} / \mathrm{EIN}$ & $0.07 \mathrm{~m}^{2} / \mathrm{EIN}$ & $0.5 \mathrm{~m}^{2} / \mathrm{EIN}$ & $0.01 \mathrm{~m}^{2} / \mathrm{EIN}$ \\
\hline 4 & Esthetic & low & high & average & high \\
\hline 5 & $\begin{array}{l}\text { Impact } \\
\text { on environment }\end{array}$ & risk of odors & low & risk of odors & low \\
\hline 6 & $\begin{array}{l}\text { Operation } \\
\text { simplicity }\end{array}$ & $\begin{array}{l}\text { troublesome } \\
\text { and high labor }\end{array}$ & $\begin{array}{l}\text { average } \\
\text { troublesome } \\
\text { and labor }\end{array}$ & $\begin{array}{l}\text { average } \\
\text { troublesome } \\
\text { and labor } \\
\end{array}$ & $\begin{array}{l}\text { low troublesome } \\
\text { and labor }\end{array}$ \\
\hline
\end{tabular}


Selection and calculation of the values of the criteria is the most difficult task in the entire analysis. It is easier if the criteria already have established values. If it is not available, a point scale can be applied. In this research, the authors used range from 0 to 6 , where 0 was least favorable and 6 was the best solution.

The analysis showed that most expensive method is use of filter bed dewatering under shed with transportation for composting. Moreover, operation is troublesome with high impact on the environment. Application of bag filters is cheaper than Bio-vt ${ }^{\circledR}$ method but has higher operation costs. This latest method, however, requires bigger land with higher risk of odor and housefly problems comparing with press filters. The most expensive method is dewatering on the under-roof beds with transportation to composting facilities. Moreover, this solution is more troublesome during the operation and with considerable environmental impact. Installations for dewatering with bag filters are cheaper in construction but more expensive at operation stage comparing to the Bio-vt ${ }^{\circledR}$ method. Solution with dewatering combined with humus production on the beds planted with grass or reeds has the lowest operation costs. However its disadvantages include: required large land area, risk of generation of odor, and low aesthetics. They may inhibit broader application of the method in Poland. It seems that least favorable method of sludge dewatering and utilization is application of drying bed [13-15].

\section{SOLUTION OF DECISION TASK}

The values of the criteria assumed for calculation are shown in Table 2, the table being a matrix of decision problems and simultaneously a formal, mathematical description of the decision problem.

Table 2

Decision matrix for calculation of most favorable dewatering and disposal technology of sludge from small wastewater treatment plant

\begin{tabular}{|l|c|c|c|c|}
\hline \multicolumn{1}{|c|}{ Criterion } & Drybed & Bagfil & Bio-vt $^{\circledR}$ & Pressfil \\
\hline Investment costs, \$ & 161760 & 88230 & 138230 & 138230 \\
\hline $\begin{array}{l}\text { Cost of composting } \\
\text { and landfilling, \$/yr }\end{array}$ & 4700 & 8820 & 2350 & 5880 \\
\hline Required land area, m²/EIN & 0.23 & 0.07 & 0.5 & 0.01 \\
\hline Aesthetics (scale 0-6) & 2 & 6 & 4 & 6 \\
\hline $\begin{array}{l}\text { Impact on environment } \\
\text { (scale 0-6) }\end{array}$ & 2 & 6 & 4 & 6 \\
\hline $\begin{array}{l}\text { Operation simplicity } \\
\text { (scale 0-6) }\end{array}$ & 2 & 4 & 4 & 6 \\
\hline
\end{tabular}


A compromising programming method was used for solving this decision problem. It allows rowing the variants from the most to the least favorable ones, using the concept of their ordering based on a distance from so-called ideal point with the axes $X^{\prime}\left(x_{1}^{\prime}, x_{2}^{\prime}, \ldots, x_{n}^{\prime}\right)$. All coordinates of ideal point are equal to maximum value of assumed normalized scale. Mathematical description of value of searched distance of analyzed variant to ideal point can be described as follows:

$$
L_{\alpha}\left(S_{n}\right)=\sum_{m=1}^{M} w_{m}^{\sigma}\left(x_{m}^{\prime}-r_{N M}^{\prime}\right)^{\alpha}
$$

while selection of best strategy is done according to equation:

$$
s_{j}=\bar{s} \Leftrightarrow L_{\alpha}\left(s_{j}\right)=\min L_{\alpha}\left(s_{n}\right), \quad n=1,2, \ldots, N
$$

where: $L_{\alpha}\left(s_{n}\right)$ - measure of difference of analyzed variant $s_{n}$ to ideal point, $s$ - analyzed strategy, $w_{m}$ - weighing coefficient of criterion $m, x_{m}^{\prime}$ - coordinate of the ideal point, $r_{N M}^{\prime}$ - normalized value of criterion, $M$ - number of criteria, $\alpha$-exponent measuring deviation of strategy from ideal point $X^{\prime}$, assumed in practice as 1,2 and $\infty$.

The method allows assigning a weight to individual criteria as well as to a group of criteria. In the calculations, there is a possibility to take into account importance of selected parameters, which are of special weight for decision makers.

As shown in Table 3, in the research, technologies were ranked from most to least beneficial, taking into account the criteria from Table 2. Ranking was notified using sign $\rightarrow$, while sign $\leftrightarrow$ was used for equivalent technologies (parallel to ideal point). Importance of criteria is listed in the first column of Table 3. For example, in the first line the technologies are ranked assuming weight of all criteria equal to 1 . In the next line, first criterion (investment costs) has got weight 2, while all other criteria are weighted as equal to 2 .

The method gives a possibility to additionally weigh the criteria through a use of an exponent $\alpha$. This exponent allows weighing each deviation from the ideal point, proportionally to their value. In other words, higher value of $\alpha$ leads to higher significance of strategy deviation from the ideal point. The results of calculations with three different exponents $\alpha$ are presented in Table 3 .

In the research, the following calculations were done:

- 48 variants were calculated, assuming different weights for each criterion, in which 38 of them, a technology with press filter was selected as most preferable.

- The Bio-vt ${ }^{\circledR}$ technology was selected 5 times in the cases when a criterions investment costs had weight 5 . 
- In the remaining 5 cases, application of filter bags was selected in the cases when significant weights were designated to the criterion investment costs.

The research showed that the solution with the bed under shed was the least beneficial one.

Table 3

Ranking of technology variants of sludge dewatering and disposal from small wastewater treatment plants ${ }^{\mathrm{a}}$

\begin{tabular}{|c|c|c|c|}
\hline $\begin{array}{l}\text { Assumed } \\
\text { criterion } \\
\text { weights }\end{array}$ & $\alpha=1$ & $\alpha=2$ & $\alpha=\infty$ \\
\hline 1:1:1:1:1:1 & $\begin{array}{l}\text { pressfil } \rightarrow \text { bagfil } \\
\rightarrow \text { Bio-vt }{ }^{\mathbb{R}} \rightarrow \text { drybed }\end{array}$ & $\begin{array}{l}\text { pressfil } \rightarrow \text { bagfil } \\
\rightarrow \text { Bio-vt }{ }^{\mathbb{R}} \rightarrow \text { drybed }\end{array}$ & $\begin{array}{l}\text { pressfil } \rightarrow \text { Bio-vt }{ }^{\mathbb{R}} \\
\leftrightarrow \text { bagfil } \leftrightarrow \text { drybed }\end{array}$ \\
\hline 2:1:1:1:1:1 & $\begin{array}{l}\text { bagfil } \rightarrow \text { pressfil } \\
\rightarrow \text { Bio-vt }{ }^{\mathbb{B}} \rightarrow \text { drybed }\end{array}$ & $\begin{array}{l}\text { bagfil } \rightarrow \text { pressfil } \\
\rightarrow \text { Bio-vt }{ }^{\mathbb{B}} \rightarrow \text { drybed }\end{array}$ & $\begin{array}{l}\text { pressfil } \rightarrow \text { Bio-vt }^{\mathbb{R}} \\
\leftrightarrow \text { bagfil }\end{array}$ \\
\hline 5:1:1:1:1:1 & $\begin{array}{l}\text { bagfil } \rightarrow \text { pressfil } \\
\rightarrow \text { Bio-vt }{ }^{\mathbb{B}} \rightarrow \text { drybed }\end{array}$ & $\begin{array}{l}\text { bagfil } \rightarrow \text { pressfil } \\
\rightarrow \text { Bio- } \mathrm{vt}^{\mathbb{B}} \rightarrow \text { drybed }\end{array}$ & $\begin{array}{l}\text { pressfil } \rightarrow \text { Bio-vt }^{\mathbb{B}} \\
\leftrightarrow \text { bagfil }\end{array}$ \\
\hline 1:2:1:1:1:1 & $\begin{array}{l}\text { pressfil } \rightarrow \text { bagfil } \\
\rightarrow \text { Bio- } \mathrm{vt}^{\mathbb{R}} \rightarrow \text { drybed }\end{array}$ & $\begin{array}{l}\text { pressfil } \rightarrow \text { Bio-vt }{ }^{\mathbb{B}} \\
\rightarrow \text { drybed } \rightarrow \text { bagfil }\end{array}$ & $\begin{array}{l}\text { pressfil } \rightarrow \text { Bio-vt }^{\mathbb{B}} \\
\leftrightarrow \text { drybed }\end{array}$ \\
\hline 1:5:1:1:1:1 & $\begin{array}{l}\text { Bio-vt }{ }^{\mathbb{B}} \rightarrow \text { pressfil } \\
\rightarrow \text { drybed } \rightarrow \text { bagfil }\end{array}$ & $\begin{array}{l}\text { Bio-vt }{ }^{\mathbb{B}} \rightarrow \text { drybed } \\
\rightarrow \text { pressfil } \rightarrow \text { bagfil }\end{array}$ & $\begin{array}{l}\text { pressfil } \rightarrow \text { Bio-vt }^{\mathbb{B}} \\
\leftrightarrow \text { drybed }\end{array}$ \\
\hline $1: 1: 2: 1: 1: 1$ & $\begin{array}{l}\text { pressfil } \rightarrow \text { bagfil } \\
\rightarrow \text { Bio-vt }{ }^{\mathbb{R}} \rightarrow \text { drybed }\end{array}$ & $\begin{array}{l}\text { pressfil } \rightarrow \text { bagfil } \\
\rightarrow \text { drybed } \rightarrow \text { Bio-vt } t^{\circledR}\end{array}$ & $\begin{array}{l}\text { pressfil } \rightarrow \text { bagfil } \\
\leftrightarrow \text { drybed }\end{array}$ \\
\hline $1: 1: 5: 1: 1: 1$ & $\begin{array}{l}\text { pressfil } \rightarrow \text { bagfil } \\
\rightarrow \text { drybed } \rightarrow \text { Bio-vt } t^{\mathbb{R}}\end{array}$ & $\begin{array}{l}\text { pressfil } \rightarrow \text { bagfil } \\
\rightarrow \text { drybed } \rightarrow \text { Bio-vt }{ }^{\circledR}\end{array}$ & $\begin{array}{l}\text { pressfil } \rightarrow \text { bagfil } \\
\leftrightarrow \text { drybed }\end{array}$ \\
\hline $1: 1: 1: 2: 1: 1$ & $\begin{array}{l}\text { pressfil } \rightarrow \text { bagfil } \\
\rightarrow \text { Bio- }-\mathrm{tt}^{\mathbb{B}} \rightarrow \text { drybed }\end{array}$ & $\begin{array}{l}\text { pressfil } \rightarrow \text { bagfil } \\
\rightarrow \text { Bio- } \mathrm{vt}^{\mathbb{B}} \rightarrow \text { drybed }\end{array}$ & $\begin{array}{l}\text { pressfil } \rightarrow \text { Bio-vt }^{\mathbb{R}} \\
\leftrightarrow \text { bagfil } \leftrightarrow \text { drybed }\end{array}$ \\
\hline 1:1:1:5:1:1 & $\begin{array}{l}\text { pressfil } \rightarrow \text { bagfil } \\
\rightarrow \text { Bio-vt }{ }^{\mathbb{B}} \rightarrow \text { drybed }\end{array}$ & $\begin{array}{l}\text { pressfil } \rightarrow \text { bagfil } \\
\rightarrow \text { Bio- } \mathrm{vt}^{\mathbb{R}} \rightarrow \text { drybed }\end{array}$ & $\begin{array}{l}\text { pressfil } \rightarrow \text { Bio-vt }{ }^{\mathbb{B}} \\
\leftrightarrow \text { bagfil } \leftrightarrow \text { drybed }\end{array}$ \\
\hline 1:1:1:1:2:1 & $\begin{array}{l}\text { pressfil } \rightarrow \text { bagfil } \\
\rightarrow \text { Bio-vt }{ }^{\mathbb{R}} \rightarrow \text { drybed }\end{array}$ & $\begin{array}{l}\text { pressfil } \rightarrow \text { bagfil } \\
\rightarrow \text { Bio- } \mathrm{vt}^{\mathbb{R}} \rightarrow \text { drybed }\end{array}$ & $\begin{array}{l}\text { pressfil } \rightarrow \text { Bio-vt }{ }^{\mathbb{R}} \\
\leftrightarrow \text { bagfil } \leftrightarrow \text { drybed }\end{array}$ \\
\hline 1:1:1:1:5:1 & $\begin{array}{l}\text { pressfil } \rightarrow \text { bagfil } \\
\rightarrow \text { Bio-vt }{ }^{\mathbb{B}} \rightarrow \text { drybed }\end{array}$ & $\begin{array}{l}\text { pressfil } \rightarrow \text { bagfil } \\
\rightarrow \text { Bio-vt }{ }^{\mathbb{R}} \rightarrow \text { drybed }\end{array}$ & $\begin{array}{l}\text { pressfil } \rightarrow \text { Bio-vt }{ }^{\circledR} \\
\leftrightarrow \text { bagfil } \leftrightarrow \text { drybed }\end{array}$ \\
\hline 1:1:1:1:1:2 & $\begin{array}{l}\text { pressfil } \rightarrow \text { bagfil } \\
\rightarrow \text { Bio- } \mathrm{vt}^{\mathbb{R}} \rightarrow \text { drybed }\end{array}$ & $\begin{array}{l}\text { pressfil } \rightarrow \text { bagfil } \\
\rightarrow \text { Bio- } \mathrm{vt}^{\mathbb{R}} \rightarrow \text { drybed }\end{array}$ & $\begin{array}{l}\text { pressfil } \rightarrow \text { Bio-vt }{ }^{\circledR} \\
\leftrightarrow \text { bagfil } \leftrightarrow \text { drybed }\end{array}$ \\
\hline $1: 1: 1: 1: 1: 5$ & $\begin{array}{l}\text { pressfil } \rightarrow \text { bagfil } \\
\rightarrow \text { Bio-vt }{ }^{\mathbb{R}} \rightarrow \text { drybed }\end{array}$ & $\begin{array}{l}\text { pressfil } \rightarrow \text { bagfil } \\
\rightarrow \text { Bio- }-\mathrm{t}^{\mathbb{R}} \rightarrow \text { drybed }\end{array}$ & 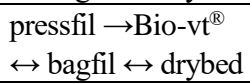 \\
\hline 5:5:1:1:1:1 & $\begin{array}{l}\text { Bio-vt }{ }^{\mathbb{R}} \rightarrow \text { bagfil } \\
\rightarrow \text { pressfil } \rightarrow \text { drybed }\end{array}$ & $\begin{array}{l}\text { Biovt }^{\mathbb{B}} \rightarrow \text { pressfil } \\
\rightarrow \text { bagfil } \rightarrow \text { drybed }\end{array}$ & pressfil $\rightarrow$ Bio-vt $^{\circledR}$ \\
\hline $1: 1: 5: 5: 5: 5$ & $\begin{array}{l}\text { pressfil } \rightarrow \text { bagfil } \\
\rightarrow \text { Bio-vt }{ }^{\mathbb{R}} \rightarrow \text { drybed }\end{array}$ & $\begin{array}{l}\text { pressfil } \rightarrow \text { bagfil } \\
\rightarrow \text { Bio-vt }^{\mathbb{R}} \rightarrow \text { drybed }\end{array}$ & $\begin{array}{l}\text { pressfil } \rightarrow \text { bagfil } \\
\leftrightarrow \text { drybed }\end{array}$ \\
\hline 5:5:1:1:5:1 & $\begin{array}{l}\text { bagfil } \rightarrow \text { pressfil } \\
\rightarrow \text { Bio-vt }{ }^{\mathbb{B}} \rightarrow \text { drybed }\end{array}$ & $\begin{array}{l}\text { Bio-vt }{ }^{\mathbb{R}} \rightarrow \text { pressfil } \\
\rightarrow \text { bagfil } \rightarrow \text { drybed }\end{array}$ & pressfil $\rightarrow$ Bio-vt $^{\mathbb{B}}$ \\
\hline
\end{tabular}

${ }^{\text {a}}$ Flow rate $Q=350 \mathrm{~m}^{3} / \mathrm{day}$, and $\mathrm{EIN}=2500$. 


\section{CONCLUSIONS}

- The decision-making process of finding the best method of treatment of sludge from small wastewater treatment plants is a complex task, where economic, environmental and social aspects should be taken into account.

- Estimation indicators proposed by experts for assessment of various technologies can serve as criteria for multi-criterial analysis, facilitating choice of the most beneficial technologies compliant with the principles of sustainable development.

- Multi-criterial analysis used as a mathematical tool in the decision-making process allowed selection of the most beneficial technology among four evaluated variants of utilization of sludge from small sewage treatment plants.

- In most cases, sludge dewatering and utilization using a filtration press with calcium sanitation was considered the most beneficial solution, and the bed under a shed with sludge transportation to composting facility - the least beneficial one.

\section{ACKNOWLEDGMENTS}

The authors acknowledge Professor Lucjan Pawłowski kind help in preparation of the manuscript.

\section{REFERENCES}

[1] Georgopoulou E., Hontou V., Gakis N., Sarafidis Y., Mirasgedis S., Lalas D.P., Loukatos A., Gargoulas Mentzis A., Economidis D., Triantafilopoulos T., Korizi K., BEAsT.: A decision-support tool for assessing the environmental benefits and the economic attractiveness of best available techniques in industry, J. Clean. Prod., 2008, 16 (3), 359.

[2] Lundin M., MOlander S., MorRison G.M., A set of indicators for the assessment of temporal variations in the sustainability of sanitary systems, Water Sci. Tech., 1999, 39 (5), 235.

[3] Mikosz J., Mucha Z., Validation of design assumptions for small wastewater treatment plant modernization in line with new interpretation of legal requirements, Ochr. Środ., 2014, 36 (1) 45.

[4] BRECHET T., TulKens H., Beyond BAT: Selecting optimal combinations of available techniques, with an example from the limestone industry, J. Environ. Manage., 2009, 90, 1790.

[5] Aragonés-Beltrán P., Mendoza-Roca J.A., Bes-Piá A., García-Melón M., Parra-Ruiz E., Application of multi-criteria decision analysis to jar-test results for chemicals selection in the physical-chemical treatment of textile wastewater, J. Hazard. Mater., 2009, 164 (1), 288.

[6] CAO Y., PAWŁOWSKi A., Energy sustainability of two parallel sewage sludge-to-energy pathways: effect of sludge volatile solids content on net energy efficiency, Environ Prot. Eng., 2012, 38 (2), 77.

[7] Generowicz A., KulCZYCKa J., Kowalski Z., Banach M., Assessment of technological solutions of municipal waste management using technology quality indicators and multicriteria analysis, Przem. Chem., 2011, 90 (5) 747.

[8] Generowicz A., Multi-criteria analysis of waste management in Szczecin, Pol. J. Environ. Stud. 2014, $23(1), 57$.

[9] Kowalski Z., Generowicz A., MaKara A., Evaluation of municipal waste disposal technologies by BATNEEC, Przem. Chem., 2012, 91 (5), 811,

[10] TECLE A., Fogel M., DuCKSTEIN L., Multi-crterion selection of wastewater management alternatives, J. Water Res. Manage., 1988, 114 (4), 383. 
[11] Benedetti L., De BAETs B., Nopens I., VAnRolleghem P.A., Multi-Criteria analysis of wastewater treatment plant design and control scenarios under uncertainty, Environ. Model. Soft, 2010, 25 (5), 616.

[12] OBARSKA-PEMPKOWIAK H., KOŁECKA K., Experiences with utilisation of sewage sludge in reed beds. Roczn. Ochr. Środ., 2006, 8, 65.

[13] Mikosz J., Wastewater management in small communities in Poland, Desalin. Water Treat., 2013, 51 (10-12), 2461.

[14] RoeleVeld P.J., Klapwijk A., Eggels P.G., Rulkens W.H., Van Starkenburg W., Sustainability of municipal wastewater treatment, Water Sci. Technol., 1997, 35 (10), 221.

[15] Bodik I., KubASKa M., Energy and sustainability of operation of a wastewater treatment plant, Environ. Prot. Eng., 2013, 39 (2), 15. 